\title{
LOCAL COMMUNITY AND POLICY MAKER PERSPECTIVES ON SUSTAINABLE LIVELIHOODS, TOURISM, ENVIRONMENT AND WASTE MANAGEMENT IN SIEM REAP/ANGKOR, CAMBODIA
}

\author{
Tahmina Rashid* \\ 20C7, Faculty of Arts and Design, University of Canberra, \\ 11 Kirninari Street, Bruce, ACT 2617, Australia \\ E-mail: Tahmina.Rashid@canberra.edu.au
}

Published online: 30 January 2020

To cite this article: Rashid, T. 2020. Local community and policy maker perspectives on sustainable livelihoods, tourism, environment and waste management in Siem Reap/Angkor, Cambodia. International Journal of Asia Pacific Studies 16 (1): 1-37, https://doi.org/10.21315/ijaps2020.16.1.1

To link to this article: https://doi.org/10.21315/ijaps2020.16.1.1

\begin{abstract}
Siem Reap/Angkor Archaeological Park is a United Nations Educational, Scientific and Cultural Organization (UNESCO)-recognised World Heritage site since 1992 and is a large operational site of enormous religious, cultural and economic importance as it generates revenue from tourism. Increased tourism has negatively impacted not only the environment but also social, cultural and economic circumstances, presenting a complex challenge for communities and policy makers. Additionally, urban expansion has stressed water resources and increased waste, adversely impacting the lives of communities and potentially threatening the Angkor temples, which are dependent upon the natural hydrological system to support these structures. Communities value the opportunities created by the tourism sector but are experiencing disenfranchisement from the policy making processes. Due to the heavy reliance on the revenue generated from tourism, policy makers are under pressure to increase tourism whilst also challenged with maintaining the supporting infrastructure. This paper examines public policy frameworks in Cambodia and argues that sustainable livelihood, tourism, environment, water and waste management are interconnected and require better community engagement in public policy making processes. The paper employs a qualitative research method and has incorporated the perspectives of policy makers and local communities in Siem Reap/Angkor. It concludes that policy makers need to incorporate the concerns


of local communities, as tourism cannot be developed in isolation given its links with local livelihoods, and urgent attention is required to better manage services needed for locals and tourists.

Keywords: Sustainable livelihoods, Siem Reap/Angkor, environment, water, waste management

\section{INTRODUCTION}

Angkor, in Cambodia's Northern Province of Siem Reap, is one of the most important archaeological sites of Southeast Asia and was recognised as a United Nations Educational, Scientific and Cultural Organization (UNESCO) World Heritage listed site in 1992. The Angkor Archaeological Park is a large operational site and contains magnificent remains of the Khmer Empire from the ninth to the 15th century, including the famous temples of Angkor Wat. Angkor (a name based on the Sanskrit word "nagara" or city) is a modern name given to the seat of the old Khmer empire. "Wat" refers to Buddhist monasteries, hence the name Angkor Wat - city of monasteries (Rabé 2008). The archaeological layout shows a high level of social order of the Khmer Empire and Angkor exemplifies religious, symbolic and cultural values, and artistic significance, not only for the local communities but also for Buddhist and Hindu religious communities around the world. Siem Reap/ Angkor attracted 5,602,157 foreign tourists in 2017 (Ministry of Tourism, Cambodia 2017) up from previous years, contributing 32.4 percent to the GDP, 30.4 percent of total employment (inclusive of effects of investment, supply chain and induced income impacts) (World Travel and Tourism Council 2018). The sites, however, face serious challenges of environmental degradation caused by an array of problems associated with tourism, urban expansion, population growth, and increased water use and waste generation, as well as negative impacts of upstream dams being built by China and Laos (Kiguchi 2016; Räsänen et al. 2017; Bernstein 2017; Brennan 2018; King 2018; Olson and Morton 2018).

Ourng et al. (2011) and Ourng and Rodrigues (2012) state that between 1993 and 2011, urban growth rate in Siem Reap was 102.51 percent. The city has expanded due to rural urban internal migration (UNESCO et al. 2018) as well as expansion of hotels to cater the tourism sector. Esposito (2014) argues that urban development driven by foreign agencies has failed, and the policy makers face the challenges of management of infrastructure and services needed for tourism sector, while for locals it means living in a permanent 
state of transition; changes to the landscape and competing interests, raising concerns regarding sustainable livelihoods of local communities. The following section provides a context for the research looking at key concepts and relevant literature.

\section{LITERATURE REVIEW}

Siem Reap/Angkor region relies heavily on the tourism industry - temples of religious and cultural significance as well as Tonle Sap lake. The livelihoods of local communities are linked with natural resources as well as heritage sites while the policy makers are responsible to manage these resources. For a better understanding of policy maker's perspective on the management of cultural heritage sites as well as tourism, this paper employs stakeholders' theory; collaboration theory, and resource-based (RB) theory in the context of sustainable livelihoods and tourism. These theories are useful to understand the role of local resources as well as potential tourism development through improved collaboration of stakeholders.

\section{Resource-based Theory}

RB theory is particularly relevant in this context, as Siem Reap/Angkor tourism as well as livelihoods largely depend on resources - tangible and intangible. This theory contends that resources are valuable, rare, difficult to imitate, and cannot be substituted due to their cultural or historical significance, and are sustainable to enable organisations to use these resources for competitive advantage to generate revenue/profit (Barney 1991; Nothnagel 2008; Hitt et al. 2016; Warnier and Weppe 2013). Conner (1991) argues that resources have to be unique to enable organisations to build a market identity/brand hence organisations develop associated human capabilities. Grant (1991) notes that an audit of organisations' resources and potential for value generation helps in identifying the strategies for maximum value generation and sustainability. Wernerfelt (1984) states that the optimal growth "involves a balance between exploitation of existing resources and development of new ones." Andersen and Kheam (1998) argue that RB theory provides "value-added theoretical explanations" of an organisations' diversification strategy and is a useful tool to predict growth rate, while Maijoor and Witteloostuijn (1996) emphasise the need to identify resources that give organisations' competitive and sustained edge in the market. While recognising the RB views' contribution in strategic management, Priem and Butler (2001) extended the understanding 
of competitive advantage argument, stating that RB theory focuses on the demand side of the market, just like environment-focused models look at the resource side alone and not the market (tourism, job creation, etc.). Responding to the critique of RB theory, Barney (2001) instructs that critical resources for sustained strategic advantage would vary depending on the nature of an organisation, as the resource value is contingent on the context. Barney and Clark (2007: 261) argue that resources are a unit of analysis and are physical in nature while capabilities are enablers for exploiting resources for competitive advantage, and emphasise the need for including the role of social welfare in these debates, a key concern for policy makers as well as local communities in Siem Reap/Angkor. Applying RB approach, Peter et al. (2011) note that economic objectives can only be achieved sustainably through sustainable preservation of natural and cultural value. Barney (2018) emphasises the need to incorporate stakeholders' perspective while applying RB theory, and in the context of Siem Reap/Angkor, it implies that policy makers as manager of resources need to manage competing interests. Gillespie (2013) argues that local communities' perceptions and expectations regarding zoning and boundaries of zones inside the park are starkly different, and considering that land is a valuable source for locals as well as policy makers, there remains the need for careful resource management.

\section{Stakeholder Theory}

Stakeholder theory and RB theory complement each other as stakeholders have vested interests in the management of resources (Harrison 2011: 107). Freeman defined stakeholders as "any group or individual who can affect or is affected by the achievement of the organization's objectives" (Freeman 1984: 49). Bonnafous-Boucher and Rendtorff $(2016: 9,17)$ are of the view that stakeholder theory is "part of the debate about role of business in society" and "implies a recognition not only of the corporation's place in the economic market but also of the social structure of the society" noting that it provides a place to incorporate ecological concerns. Donaldson and Preston (1995: 71) argue that there are three aspects of the stakeholder theory, descriptive/ empirical, the instrumental and the normative. The first one is related to different elements of tourism industry and the connection among stakeholders; the second deals with specifics actions and results and the last one interprets "the function of the corporation, including moral or philosophical guidelines" for managing bodies. Friedman and Miles (2006) and Sachs and Ruhli (2011) include customers, suppliers/distributers, employees, politicians, unions, 
government, business partners and local communities as shareholders. Freeman et al. (2010) are of the view that stakeholder theory is a "set of shared ideas" and echoes the idea that people need to jointly seek and create meaning within organisations (Freeman et al. 2010: 29, 79). Orts and Strudler (2002) and Donaldson (2011) stress the need to acknowledge the rights of all stakeholders especially local communities as moral if not legal responsibility of corporations. Oels (2006) emphasises the need to ensure a formal mandate for stakeholder dialogue by elected authorities and a willingness to share power with local communities as stakeholders for meaningful collaboration. Sachs et al. (2009) suggest taking into consideration the political and social stakeholders, their needs and expectations as it impacts the sustainability. Freeman argues for placing stakeholders' interests at the heart of the strategic management and "that managers need to understand the world from the stakeholder's point of view." He states that stakeholders' interests are aligned and creating value for stakeholders does not involve "trade-off thinking" (Freeman 2011: 229). D'Anselmi cautions for stakeholder engagement with right counterparts rather than only "interested" and known stakeholders, noting that unknown stakeholders who do not have a voice needs to be included (D'Anselmi 2011: 52). Orr (2014) emphasises the need to understand the scope of the problem while identifying stakeholders and the significance of stakeholders' participation in the decision-making process arguing for closer collaboration so that citizens' views are not only heard but incorporated rather than interpreting their voices. Byrd (2007) urges that stakeholder's identification to be "based on the stakeholder's interest in the organisation, not the organisation's interest in the stakeholder." Pesqueux and Damak-Ayadi (2005) argued that the policy makers have an interest in fostering stakeholder collaboration, as they share resources, and their participation has to be inclusive, equitable and beyond tokenism.

\section{Collaboration Theory}

Gray's seminal work (1985) on solving the wicked problems (Rittel and Webber 1973) through interorganisational collaboration stresses the need for collaboration as "viable and necessary approach." She notes that complex problems require collaboration among various sectors, business, communities and governments, proposing models for such intersectoral approach for advancing shared vision, emphasising that all relationships in the system are important. Extending Gray's arguments that collaboration is a flexible and dynamic process that continues to evolve enabling shared solutions for shared 
problems, Jamal and Getz argue that stakeholders are independent entities, and solutions are sought through a process of collaboration, and owned collectively. They contend that "strategic planning for tourism destinations is a complex task due to the interdependence of multiple stakeholders and fragmented control over the destination's resources" suggesting sharing of resources through a collaboration process (Jamal and Getz 1995: 200). Jamal and Stronza opine that application of collaboration theory for "tourism planning and protected areas" is gaining traction to "manage growing concerns over climate change, biodiversity loss, resource depletion and impacts of globalization on indigenous and local communities" (Jamal and Stronza 2009: 169). McNamara makes a distinction between cooperation, coordination and collaboration, arguing that collaboration requires closer relationship, connection and sharing of resources. She stresses the need for collaboration to deal with the complex nature of problems arguing for collective responsibility (McNamara 2012: 391). Colbry et al. note the significance of collaboration theories across organisations and stakeholders (2014). Ansel and Gash (2007) and Emerson et al. (2012) extend collaboration theory and framework by bringing collaborative governance in the discussion, emphasising the need for constructive engagement. While reviewing number of environmental management case studies, Margerum (2008) notes "action, organisation and policy collaboratives" as a useful typology. Agranoff states that agencies often work "under different mandates and towards different goals" hence the need for collaboration, noting that to solve "wicked problems" concerted action over a longer period requires maximum engagement with regular collaborative interactions between the public sector and civil society, arguing for "boundaryless world" without elimination of hierarchies (Agranoff 2012: 13, 16). In this context, Williams' argument that collaboration should always be "seen through a lens of context" (Williams 2016: 37) is really important for sustainable tourism management from the perspective of all stakeholders in Siem Reap/Angkor.

\section{Sustainable Tourism Development}

Sautter and Leisen (1999) argue that tourism planners need to accommodate the interests of all stakeholders for benefitting collectively. Citing Kim (1991), they suggest that local culture, heritage and lifestyle should be valued similar to the economic value and passed on to the next generations. While recognising the structural, operational and cultural limits to community participation in the tourism development process, Tosun emphasises the need to create opportunities for local communities to participate in the decision-making process rather than 
focusing on employment or small-scale business opportunities (Tosun 2000: 626). Winter (2008) has highlighted the significance of sustainable Angkorean tourism in Cambodia from the tourism and community perspectives, without losing focus from conservation. Peter et al. (2011) emphasise the need to rediscover "the value of endogenous cultural attractions and regional entities" and their uniqueness and high differentiation potential as tourism destinations. Barney et al. (2011) argue that local communities as stakeholders can raise cultural awareness and offer a unique and authentic experience to tourists, emphasising the role of authenticity in developing unique and niche products and services, while using resources sustainably. The concept of sustainable tourism is especially relevant, as unlike economic value of tourism, cultural experiences cannot be measured, and Siem Reap/Angkor offer a unique experience.

\section{Sustainable Livelihoods}

In their influential work on sustainable rural livelihoods, Chambers and Conway (1992) argue that:
A livelihood comprises the capabilities, assets (including both material and social resources) and activities required for a means of living. A livelihood is sustainable when it can cope with and recover from stresses and shocks, maintain or enhance its capabilities and assets, while not undermining the natural resource base.

Extending their work, Scoones (1998) proposed understanding the context, livelihood resources, and institutional and livelihood strategies to achieve sustainable livelihood outcomes. He argued that sustainable livelihood indicators include: gainful employment; poverty reduction; well-being and improved capabilities of local communities; livelihood adaption, vulnerability and resilience; and natural resource-based sustainability. Bebbington (1999: 2022) extends the arguments from the rural communities' livelihood perspective, noting that land is not only a source for earning a living but it gives individuals an identity in the world, "power to act and to reproduce, challenge or change the rules." Scoones and Wolmer (2003: 5) highlight the urgency to employ a sustainable livelihood approach to understand the consequences of development from livelihood of poor communities' perspective at all institutional and policy level. Building on Scoones' work, Morse and McNamara (2013: 28) identified natural, human, social, physical and economic as key to sustainable livelihoods, supporting evidence-led 
policies. This research argues that any sustainable development model needs to put greater emphasis on the inclusion of local community perspectives in the policy development and decision-making processes.

In his extensive work on Angkor, Winter noted that since the 1990s the issue of development was largely ignored as the focus remained on "the protection and restoration of the temples' architecture." Within this conservation paradigm, development, tourism and the generation of capital were all perceived as threats, impending dangers and issues to be resisted (Winter 2008: 532). He notes that tourism was largely ignored by foreign aid industry that remained focused on traditional industries and export of timber and rubber. Mao et al. (2014) conclude that despite recognition of the linkage between agriculture and tourism by the Cambodian government, it has not resulted into actions from local farmers' perspective. Farmers face multiple constraints such as small land holdings, shortage of skilled labour, price fluctuations as well as lack of knowledge of the hospitality industry needs. Small farmers cannot compete with big suppliers of imported produce, and access to finances remains a challenge for expanding and innovating farming techniques; also noting the exclusion of some villages from accessing extension services due to the limitations of Angkor zoning. Importing food has economic implications as tourism revenue continues to fly out of the country (Chheang 2008: 293), while local farmers face constraints including access to markets, and agro-ecological factors like unreliable rainfall, environmental degradation and barren soils, resulting in water and food insecurity.

Siem Reap/Angkor has significant natural resources, aided by the protection of forests around Angkor temples as part of tourism development, contributing towards the environmental sustainability in the region. Water remains critical for the stability of sandstone temple structures (Andre et al. 2014; Chamroeun 2017; Liu et al. 2018), any changes in the ground water level whether due to extraction (Doherty 2010) or changes due to "seasonal variations of the groundwater table and the thermodynamics of stone materials are factors that could trigger and/or aggravate the deterioration of monuments" (Chen et al. 2017). Chamroeun's work for UNESCO (2015) on the water systems in Siem Reap/Angkor notes that in the ten villages studied, rural communities rely solely on groundwater for domestic use and nearly 20 percent have problems in accessing water during the dry season. The participants in his study confirmed that they produce only one crop per year due to the lack of water and have limited income as well as food from subsistence farming. Chamroeun concludes that the available ground/surface water in Siem Reap/ Angkor is insufficient to meet the demands of the tourism industry, and 
water reserves are depleting to unsustainable levels. As the communities and businesses rely on groundwater, there are serious concerns for the stability of Angkor temples - the star attraction for tourism in the region.

Internal migration continues as employment opportunities created by the tourism sector attract youth from other provinces, adding pressure on utilities such as water and waste management (Bharam 2012; Chheang 2010; Ponna and Prasiasa 2011). Due to its smaller population (compared to Phnom Penh), Siem Reap has attracted nominal foreign direct investment (FDI) and its economy continues to rely on tourism industry (Hakim 2018), implying that tourism would remain a key revenue generating source and sustainable management of resources related to tourism on Siem Reap/Angkor from all stakeholders perspective would remain critical. The challenges associated with tourism, restoration of temples and socio-economic needs of local communities require ecologically sustainable agriculture, aquaculture, forestry, water management, tourism and social development (Soubert and Soung 1995). Inadequate waste management is also impacting the quality of surface and groundwater with flow-on consequences for the adjacent Siem Reap River, Tonle Sap River and Lake (Chamroeun 2017). The Siem Reap River connects to the ecologically and economically significant Tonle Sap Lake (a 1997 UNESCO-nominated Biosphere Reserve). Poor water quality impacts on the ecology of the lake, including on the fish populations in the lake, a key source of protein for local communities.

\section{RESEARCH METHODOLOGY}

This research employed a qualitative research methodology guided by a transformative paradigm that places central importance on the lives and experiences of diverse groups that have traditionally been marginalised. This approach facilitated the local community members to share experiences, stories and knowledge. The rationale for choosing a qualitative approach for data collection is based on the established social science research method that aims to understand the socio-environmental perspectives of communities. This study is exploratory in nature and aims to understand the perspective of policy makers and communities within the context of their lived experiences (Seidman 2013). The research was designed in two stages: a document analysis stage that guided the processes; and a field study stage using a qualitative research approach that involved various stakeholders. At the first stage, available literature and the legal frameworks in which the policy makers 
operate were examined. This guided the fieldwork in Siem Reap/Angkor and enabled identification of communities that would inform the research through thematic conversations. Field interviews were based on unstructured interview questionnaires (one for policy makers and the other for community members) in the ethnographic research tradition (Laws et al. 2003; Alonso 2017) and were conducted in formal and informal settings (DeWalt and DeWalt 2011). Visits to various sites in Siem Reap/Angkor were planned for observing various facilities such as waste management, waste disposal, water pollution, etc., a recognised research technique (Gerson and Horowitz 2002: 202; Tolley et al. 2016: 86) to validate information collected from stakeholders (Angrosino 2007: 54, 57; Denscombe 2010: 197). Extensive notes and photos were taken to record information and validate the information provided by stakeholders (Clifford 1990; Punch 2014). Confidentiality of informant's identity was guaranteed as many public officials only spoke on the condition of anonymity and in line with Human Research Ethics policy of the university, their names and institutional affiliations have been withheld (Banks and Brydon-Miller 2019; Surmiak 2018; Shane 2016; Dabney and Tewksbury 2016; Kaiser 2009; Gregory 2003).

This research had limitations in terms of time spent in the field, language and access to the local communities and policy makers in Siem Reap/Angkor. These limitations were overcome with advance planning. The fieldwork was conducted over a period of three weeks (18 March-8 April 2016), however the meetings were organised in advance and documents have been analysed before conducting the fieldwork. A local research assistant was hired to assist before the field work to conduct research, assist with planning and conducting interviews with policy makers, local communities and site visits. Meetings with various public offices were organised through local UNESCO office and with the assistance of the Authority for the Protection and Safeguarding of Angkor and the Region of Angkor (APSARA). Despite advance planning, all meetings did not materialise, and some meetings with public officials either did not materialise or a different official in the same department was nominated. Another limitation is not focusing on gender as a category while conducting fieldwork, as "family unit" was used as a unit of analysis. The following table provides details of the key stakeholders identified and interviewed: 
Table 1: List of informants.

\begin{tabular}{lc}
\hline Departments and research sites & Number of interviews \\
\hline APSARA & 2 \\
Department of Tourism & 1 \\
Department of Land Management & 1 \\
Department of Water Resources and Meterology & 1 \\
Department of Environment & 3 \\
Department of Public Works & 6 vendors and 6 community members \\
Kampong Phluk village & 6 community members \\
Bakong commune (near Bakong temples), District & \\
Prasat Bakong & 6 vendors, 6 community members, \\
Sras Srang village & 1 village elder \\
& 6 vendors \\
Phsar Leu Thom Thmey (Leu Market) & 8 vendors \\
Phsa Samaki & 12 vendors \\
Psar Chas (Old Market) & 8 vendors \\
Angkor Arts Night Market & \\
\hline
\end{tabular}

Stakeholder identification was informed by the models developed by CANARI (2011), Eden and Ackerman (1998), and Nutt and Backoff(1992). The research sites in three districts are marked in Figure 1.

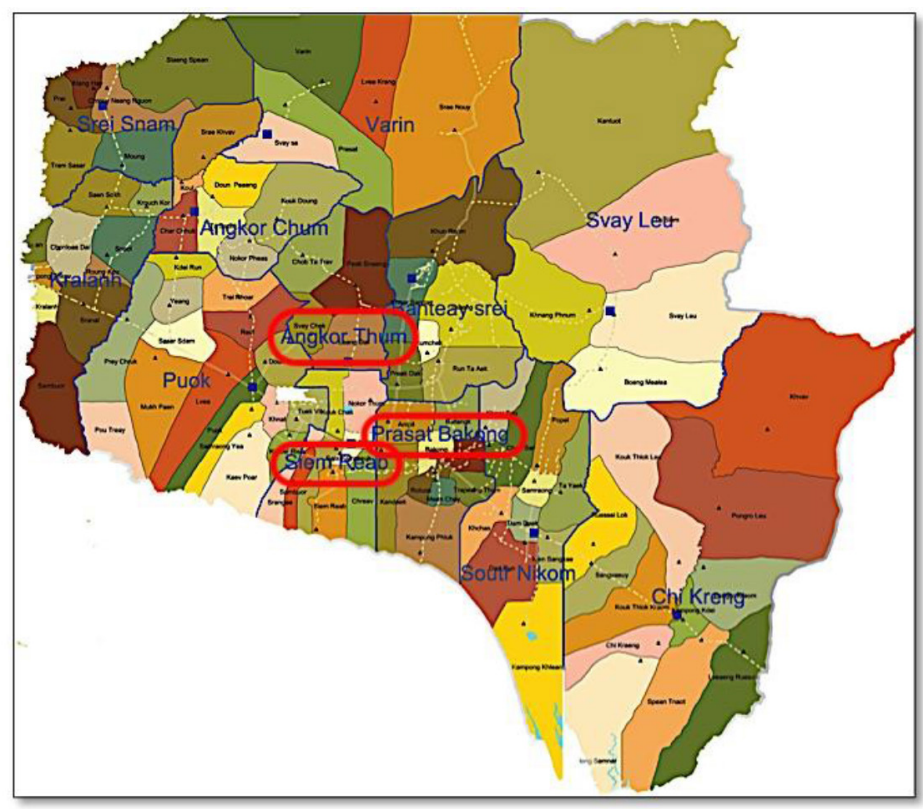

Figure 1: Administrative map of Siem Reap province (source: GSID 2013).

Unstructured interview questionnaires were designed after reviewing the available resources and legal framework; however, small modifications were made in consultation with local research assistant. During the interviews and discussions, follow-up questions were asked to seek clarification and additional 
information. Data collected from public offices is primarily the policy maker's perspective on various initiatives as well as challenges faced during policy making and implementation processes. Local communities' perspective on changes taking place in their surroundings and lived experiences were collected as stories and narratives. Data collected from policy makers' interviews is presented according to their department, while local communities' perspectives are organised according to the emerging themes and not locations though the zoning of archaeological park has some site specific challenges, as noted in the section on the perspective of communities, however conclusions are drawn based on all the data.

The next section provides an overview of the policy framework related to the environment, water, sustainable development, culture and tourism.

\section{REGULATORY FRAMEWORK}

The regulatory framework in Cambodia to manage tourism, the environment, water, culture and development has been taking shape for quite some time. Cambodia has ratified several international policies for sustainable development, as well as signed several multilateral conventions and agreements, yet does not have a formal National Agenda (United Nations 2012). Cambodia endorsed the Green Growth Roadmap in 2009, which outlines a framework for environmental sustainability and socially inclusive development. This roadmap has focused on equity, poverty reduction, cultural diversity, water resource management and climate change. There are at least two royal decrees specific to Siem Reap/Angkor in the relevant policies stated below:

- 1994 Royal Decree on The Establishment of Protected Cultural Zones in The Siem Reap/Angkor Region and guidelines for their management

- 1995 Royal Decree on The Establishment of APSARA

Relevant legal/policy framework for the protection of culture includes:

- 1993 Royal Decree on Creation and Designation of Protected Areas

- 1996 Law on the Protection of the Cultural Heritage 
Relevant legal/policy framework for the protection of environment includes:

- 1997 Sub-Decree No. 57 on the Organisation and Functioning of the Ministry of Environment

- 1999 Sub-Decree No. 72 on Environmental Impact Assessment

- 2000 Sub-Decree No. 42 on the Control of Air Pollution and Noise Disturbance

Relevant legal/policy framework for waste management includes:

- 1999 Sub-Decree 36 on Solid Waste Management

- 2015 Sub-Decree No. 113 on Urban Garbage and Solid Waste Management

Relevant legal/policy framework for water resource management includes:

- 1999 Sub-Decree No. 27 on Water Pollution Control

- 2007, 29 June Water Resources Management Law in Kingdom of Cambodia

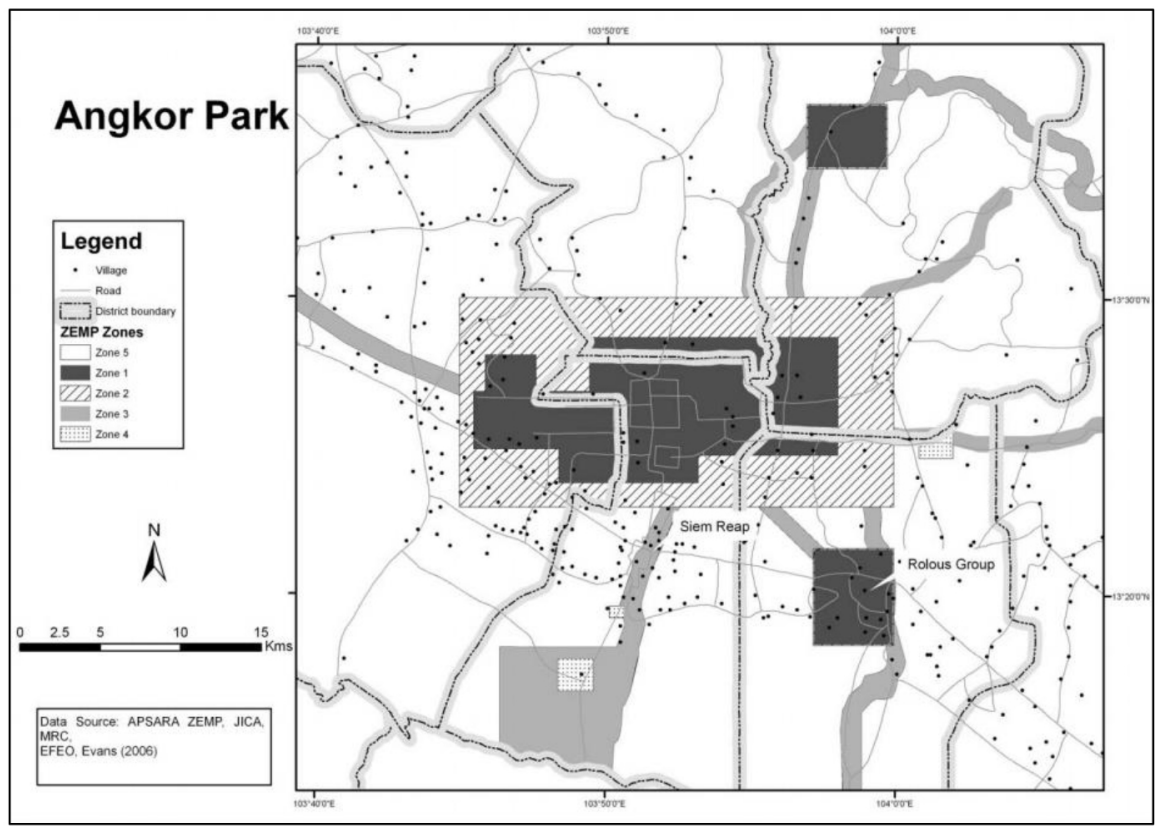

Figure 2: Angkor Archaeological Park zones (source: Gillespie 2013).

Siem Reap/Angkor Park (Figure 2) are key attractions for tourists and contribute significantly to the economy. The following tables provide a snapshot of the tourists visiting the region as well as highlights the numbers arriving for business purposes. 
Table 2: Percentage share of tourists by country.

\begin{tabular}{rrrcrcrc}
\hline China & Vietnam & Laos & Thailand & Korea & United States & Japan & Malaysia \\
\hline 21.6 & 14.9 & 9 & 7 & 6.2 & 4.6 & 3.6 & 3.2 \\
\hline
\end{tabular}

Source: Tourism Statistics Report 2017, Ministry of Tourism, Cambodia

Table 3: Number of tourists arriving for business purpose.

\begin{tabular}{ccccccccc}
\hline China & Vietnam & Thailand & Japan & Taiwan & Korea & Indonesia & Malaysia & Philippines \\
\hline 159,588 & 42,143 & 22,380 & 21,741 & 17,418 & 15,510 & 12,490 & 11,480 & 10,054 \\
\hline
\end{tabular}

Source: Tourism Statistics Report 2017, Ministry of Tourism, Cambodia

The numbers in Tables 2 and 3 highlight the country of origin of tourists as well as those coming for business purposes. Winter (2008) has rightly noted that policy makers are challenged by the "paradoxical and unstable agendas - heritage conservation and tourism development" in a resource constrained environment. Choulean admitted lack of focus on improved livelihoods of local villages as foreign funding was for the preservation of Angkor temples, noting that dual jurisdiction are one of the challenges faced by APSARA and Ministry of Culture (TaleofAsia.com 2000).

\section{DISCUSSION AND FINDINGS FROM CONSULTATIONS WITH POLICY MAKERS}

This section is based on the interviews of officials from different departments organised through UNESCO office and local research assistant and in line with the confidentiality clause and research ethics policies, names of individuals interviewed have not been included.

\section{Tourism Management}

For APSARA and the department of tourism, increasing tourism is a common goal as it generates revenue that is crucial for the management of heritage sites as well as improve infrastructure in Siem Reap/Angkor to cater the tourists but also generate employment opportunities for locals and migrants from other parts of Cambodia. APSARA officials interviewed noted that they would like UNESCO heritage listing extended to the area adjoining Angkor Wat to include additional adjacent temples, and have been working towards this goal (Sotheary 2017). They argue that this would enable better protection of these additional sites and add to tourism attraction. The department of 
tourism highlighted that Angkor National Museum and ticketing at Angkor Wat temples contribute enormously to revenue generation, along with hotels and associated tourism services. Angkor Enterprise (2017) states that in 2017, 2,457,023 tourists visited the temples, an increase of 12 percent from 2016 $(2,197,254)$, while Spiess (2018) noted that the revenue from ticket sales has gone up to USD108 million. Tourism data indicates that the number of tourists arriving at Phnom Penh and surrounding regions $(3,144,875$ in 2017) is still higher than Siem Reap Angkor (2,457,282 in 2017), hence the efforts to increase these numbers, while for APSARA high-end tourism remains a preference considering their mandate for the preservation of temples. One can understand these paradoxical interests in increasing the number of tourists as well as preserving resources in archaeological park.

\section{Land Management}

Land management in Cambodia is a complicated issue due to customary practices, colonial laws and traditional community ownership and continues to be a challenge for policy makers. Sekiguchi and Hatsukano (2013) state that:

The attempt to reform the legal system has been so rapid that there has been little chance to incorporate the traditional legal concepts rooted in local society with more modern concepts of land law. As a result, land policy has become a quilt of overlapping systems, some reaching back centuries, some recent: customary law, the French Civil Code, socialism, private ownership under modern law, and land registration systems.

Land Management Department and APSARA deal with complex issues arising from rapid urbanisation, land disputes, and re-zoning of land and work in a challenging environment with competing vested interests. The Land Management authority's work is informed by the "Integrated Master Plan for Sustainable Development of Siem Reap/Angkor Town in the Kingdom of Cambodia." The department officials noted that for the last four years, a land management plan has been awaiting approval, however, various public departments are implementing it regardless. As the land is a high value resource, urban expansion and the need to access land for commercial ventures remains high, which in turn is changing the landscape. These changes in land use require collaboration between various departments and ministries (infrastructure/water/public works), and are impacted by the land ownership 
system and the absence of a land management plan. Gillespie (2013) notes that public awareness regarding zones is limited (if any), and it is only recently that APSARA has installed boards for public information and awareness regarding the sale of land in different zones of Angkor (Sotheary 2019). Winter (2008) noted the construction boom, resulting from hotels, restaurants as well as housing due to internal migration, this trend continues as was observed during the filed visit in Siem Reap region.

\section{Water Resource Management}

Water Resource Management Law 2007 recognises the rights of individuals to access water without affecting the rights of others, as well as noting that drilling or digging of wells for professional or commercial purposes requires a licence. Article 22 mandates that "The discharge, disposal or deposit of polluting substances which are likely to deteriorate the quality of water and to endanger human, animal and plant health shall be subject to water licence or authorisation." The department collaborates with APSARA as adequate groundwater reserves are required for the structural stability of Angkor temples in addition to fulfilling the consumption needs of local communities and the tourism industry. There are four main sources of water in the province - Siem Reap River, West Baray, Tonle Sap Lake and groundwater, and only eight out of 12 districts get their water supply from public supply system, the rest rely on groundwater for all their needs. Water resource management department official interviewed noted that the law neither applies retrospectively nor requires the hotels established before 2007 to stop accessing groundwater or to install water meters to gauge the amount of water extracted. The situation raises questions about the accuracy of data on the depletion of groundwater reserves raising concerns for the future management of water, sewerage and environment.

\section{Environmental Management}

The Department of Environmental Management works in collaboration with APSARA as well as national bodies for environmental protection and conservation, air and noise pollution, biodiversity conservation, wildlife sanctuaries, fire-protected areas of Angkor, national parks, waste management and natural resource management. Considering the dual jurisdictions, the nature of relationships is complex as noted by the department official. The department is responsible for environmental impact assessments (EIAs) for small investment projects; however, the national ministry handles large 
investment projects and collaboration between the two in terms of EIA data sharing was noted as a key challenge. The pressure on natural resources puts pressures on the environment, exacerbated by tourism and urban growth in Siem Reap impacting local communities. Environmental management is critical for maintaining forests around temples, hence the need to protect wetlands and increase public awareness in a resource constrained environment. Liquid and solid waste management impacts water resources and the environment, critical for the preservation of heritage sites requiring collaboration between provincial and national ministries as well as APSARA.

\section{Liquid and Solid Waste Management}

Public Works Department (PWD) is responsible for the management of liquid and solid waste systems in Siem Reap. Currently, the sewerage system caters to the 50 percent of the total need of Siem Reap, predominantly to the densely populated districts. Asian Development Bank (ADB) report (2012) noted that despite discussions on "user pays fees" and "polluters pay principles" the low coverage of piped water and sewerage, and lack of a functional system for real estate tax did not lead to formulation of any major policy. At the time of this research, PWD noted the challenges of the lack of branch sewers connected to the trunk sewer, resulting in uncontrolled direct discharge to open drains causing sanitation problems. The aging infrastructure has reduced capacity due to sedimentation; open drains are clogged; and lack of proper material, tools and equipment result in substandard operational management. The capacity of the existing system as well as human resources is a challenge as noted by Winter (2008). He noted that local scholars were trained in geographic information systems (GIS); however, at the time of this research PWD official noted the absence of GIS data (in 2016 only one Japanese volunteer was working at the facility as GIS specialist). PWD shared the following figure to illustrate the type of existing sewerage system structure in Siem Reap city that needs upgrading to improve and expand the services. 


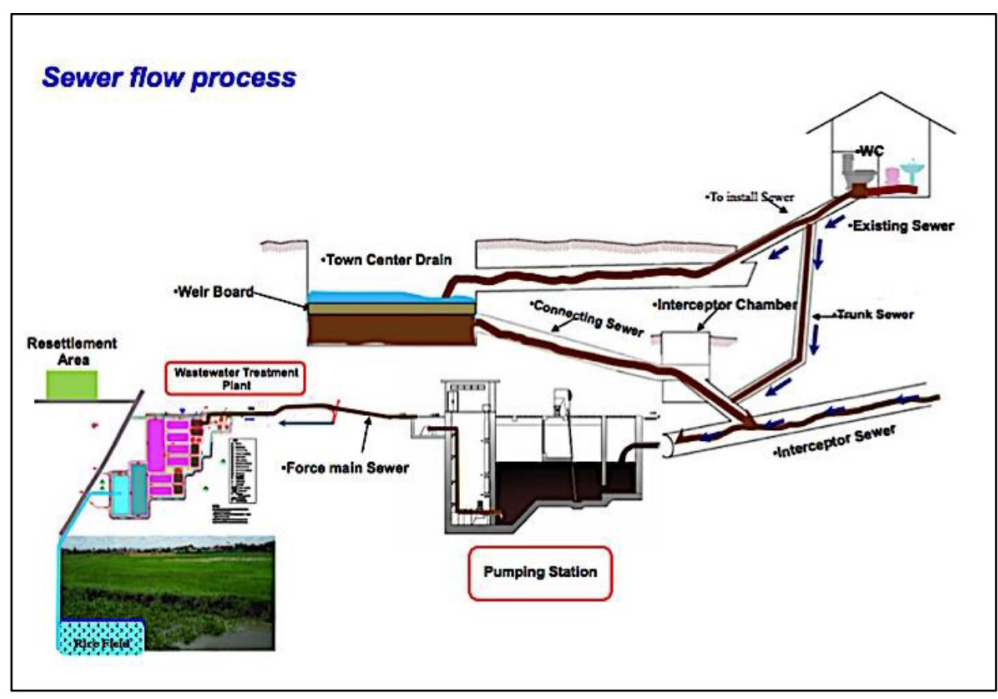

Figure 3: Existing sewerage flow system (images shared by PWD, Siem Reap, Cambodia).

The following figure shared by PWD highlights the challenges faced by the existing drainage and the sewerage system.

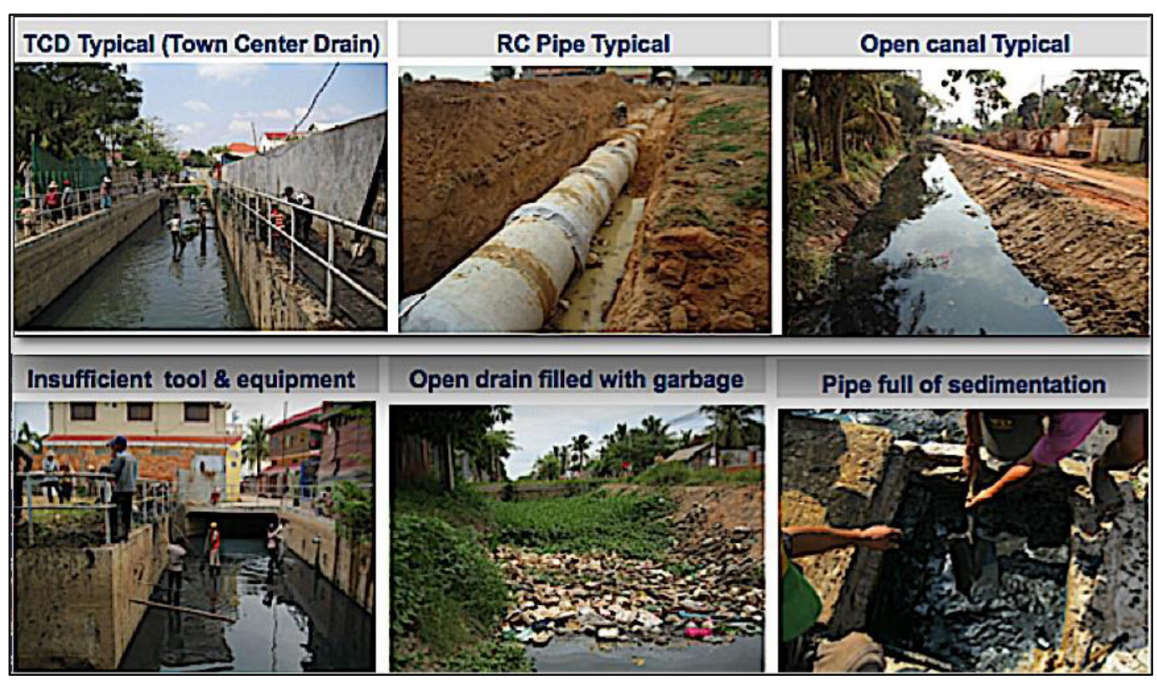

Figure 4: Existing storm drainage system and challenges (images by PWD, Siem Reap, Cambodia).

The public policy maker's perspective highlights what Winter (2008) noted as "paradoxical agendas" regarding increased tourism, heritage conservation, water resource management and management of environment. It also highlights the need for closer collaboration between public offices and communities whose lives are directly impacted by policies related to tourism, waste management and natural resource management. 


\section{DISCUSSION AND FINDINGS FROM CONSULTATIONS WITH THE LOCAL COMMUNITIES}

Visvanathan (2009) argues for valuing community perspectives and concerns in public policy making, especially when business/commercial interests and scientific knowledge is used to inform public policy to the disadvantage of local community concerns and interests. She contends that no industry should be considered as a "more eligible citizen" than the locals whose livelihoods depend on natural resources. She notes that such exclusions also destroys "a common body of knowledge about trees, fodder, forest produce, seeds, medicines, ... not merely a resource pool but a way of life that sustained a way of knowledge" and argues for a meaningful dialogue with all stakeholders, listening to and understanding all perspectives (Visvanathan 2009: 153, 155), assigning equal value to "expert knowledge" and traditional local practices. Recognising the relationship "between knowledge and livelihood and lifestyle... policy must not be articulated within one monochromatic frame of knowledge but within an existential plurality of them" (156). To understand the impact of tourism and associated changes at the research sites, discussions with vendors, small retailers and local community members were conducted in and around the following areas:

- Kampong Phluk (floating village at Tonle Sap Lake, District Prasat Bakong)

- Bakong commune (near Bakong temples, District Prasat Bakong)

- Srah Srang Village (near Angkor)

- Phsar Leu Thom Thmey (Leu Market, Siem Reap city)

- Phsa Samaki (Samaki Market, Siem Reap city)

- Psar Chas (Old Market, Siem Reap city)

- Angkor Art Centre Market (Siem Reap city) 
The following figure identifies the research sites:

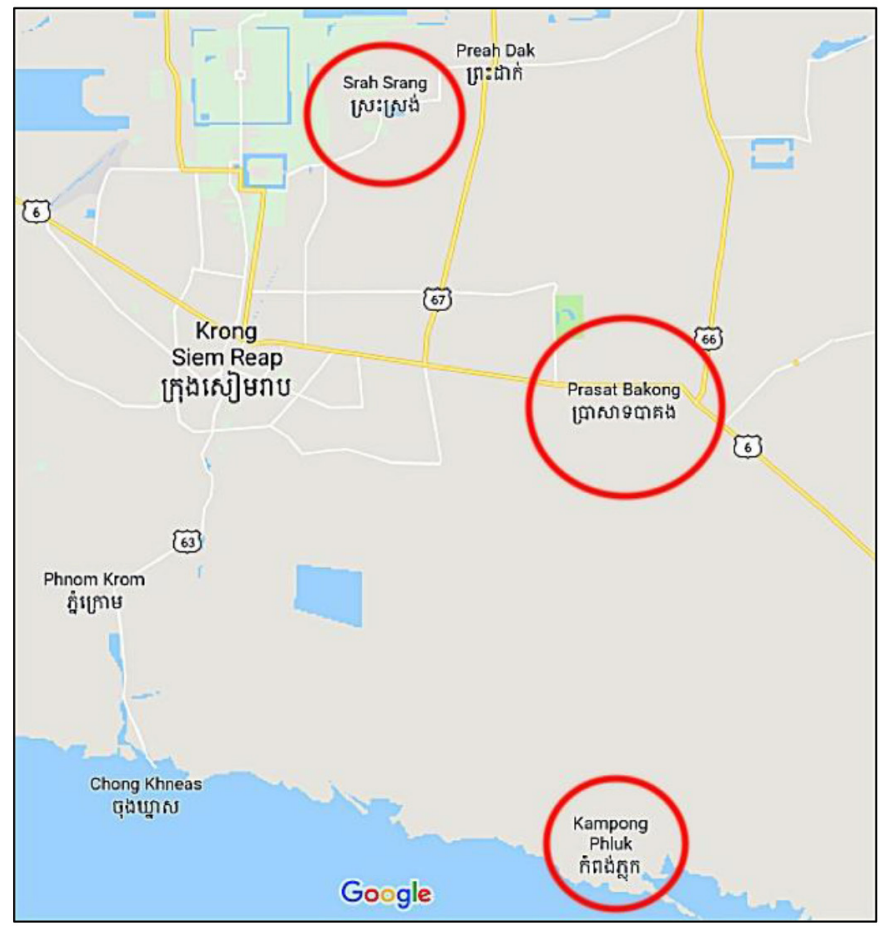

Figure 5: Research sites for community consultation.

In the following section, community perspectives are discussed according to the themes that emerged from the field data collected from these sites.

\section{Impact of Tourism on Local Communities}

Social research suggests that tourism has deep socio-cultural impacts on the host communities' culture, lifestyle and well-being. The range of socio-cultural, economic and environmental impacts in Siem Reap/Angkor emphasise the need for effective integration of community perspectives to achieve sustainable tourism development, planning and policies. The socio-environmental impact of tourism is generally considered negative though increased tourism pushes for improvement of environmental resources as the revenue generated from tourism creates an enabling environment. Local communities benefit economically, as business investments create employment as well as a market for locals to sell handicrafts to foreigners. Eng's work (2010) in Srah Srang Cheung village, one of the sites in Angkor Archaeological Park, where this research was conducted, noted the positive changes such as improved living standards, and employment with higher returns as compared to agricultural work, while inflation and lack of savings was noted as negative changes. Since the villages inside Zone 1 have restrictions on land use and natural resources, 
community perceptions vary. Villages close to the temples generate enough income to survive by selling souvenirs to foreign tourists during the peak (February to May) tourism season and food (mainly) to Cambodian tourists. Villages located away from the main roads leading to Siem Reap indirectly benefit from tourism by making various handicrafts, which are either sold in the local market or to a middleman.

Local communities as well as vendors note that they miss out the economic benefits enjoyed by big businesses and outsiders; these concerns were also raised by vendors in the local markets. Mao's work on tourism's role in poverty reduction corroborates the findings of this research, he notes that economic leakage is higher than the official figures, and attributes this to lack of capacity of the local producers to supply the quantity and types of consumables required, as well as foreign companies associated with tourism - hotels, airlines, tour operators, tour packages bought in the country of origin, and business partnerships between foreigners and locals (Mao 2015: 84-85). He indicates that locals often have insufficient market knowledge; poor connection and linkages between farmers and tourism industry, and an inability to compete with foreign imports (Mao 2015: 142).

\section{Tourism and Youth}

While villages near the temples have schools and easy access to Siem Reap institutions, floating village has a primary and secondary school (Grades 1-11) and only a small number of families can afford to send their children to a vocational institute or university. Youth from poorer families stay in the village, making a living by working with their families, eventually taking on fishing and subsistence farming. The financial stress caused by a prolonged dry season and environmental stresses has long-term implications for youth as it limits skill development and employment in the tourism industry. At the time of the fieldwork, a road was under construction (funded by the local commune) to connect the villages to Siem Reap that would improve access to education, health and employment opportunities. Eng's research noted child labour through tourism was seen positively by Srah Srang communities, as the money earned could be used to pay for learning the language of tourists or vocational skills (Eng 2010: 150). School dropout was noted by Choulean as one of the concerns for policy makers (TaleofAsia.com 2000). As the number of tourists varies between dry and wet (high/low) seasons, the income earned through various activities fluctuates, and during financial hardship, village youth searches for work on construction sites or migrates to (mainly) Thailand to work on fishing trawlers. 


\section{Impact of Tourism on Local Culture}

Tourism is seen as a factor for cultural and psychological change with profound effects on attitudes, beliefs, worldview, and on the concepts of work, money and human relationships. It has also been noted that increased tourism impacts on ties that bind people to place, faith, culture and aesthetics. The facilities developed to entertain tourists often disrupt local culture and the social fabric of society, and lead to changed social and cultural behaviours alien to these communities (Soubert and Soung 1995). Candelaria (2005) noted increase in sex tourism in Cambodia, potentially leading to social and health issues. Chheang (2008: 293) has noted the increase in the spread of HIV and AIDS as well as recognition of Cambodia on "child sex tourism map." Ministry of tourism's "committee for the safety of child in tourism" was established to increase public awareness yet the constraints remain. Brickell's extensive work on drunkenness and gendered violence and its links with the socio-economic changes occurring in post-conflict Siem-Reap (Brickell 2008), echoed the sentiments of local participants of this research who noted that increased tourism and bars have led to increase in drug use especially among youth. Dolezal and Trupp (2015: 118) have paid particular attention to the changes in socio-cultural dynamics including gender relations. Locals may not articulate their concerns regarding these changes in terms of loss of culture, however they clearly articulate changes in attitudes and behaviours of locals, especially eating habits and changing notion of self.

\section{Water Resources - Access and Related Challenges}

Challenges related to water resource management was a theme that emerged in public policy perspectives, however, for communities the issues are closely linked to their daily lives as well as livelihoods. Tonle Sap Lake provides water for half of Cambodia's crops, and yields fish that supply protein to half of its population (Hays 2008). It is connected to the Mekong River system by a short river (Tonle Sap River) and in the wet season (June to October) becomes an inland sea filled with water flowing from the Mekong River. In the dry season (November to May), the water flows out to the Mekong River with the lake shrinking to its normal size by the end of the dry season. During the wet season, surrounding farmlands and forests are submerged and stilted houses and floating villages lie in the middle of the lake.

Kampong Phluk — one of the floating villages (Kampong Phluk, Prasat Bakong district) - is a major tourist attraction during the wet season. Village huts are located at a considerable height to cope with the rising lake water 
during the wet season. When the water level recedes in the dry season, residents engage in alternative work to make a living. During the dry season, the locals convert the basement of these huts into small retail shops, selling utilities, food and crafts. Water supply was noted as a crucial issue, as Kampong Phluk does not have access to piped water and relies on groundwater for daily needs. Villagers stated that a few years ago, for a brief period, a civil society organisation assisted with piped water supply; however, the service discontinued when the project funding ended. Those who can afford to access groundwater have a regular supply of water, however, a number of households use lake water, buy water or ask neighbours for permission to access water, especially during the dry season.

Villagers in Prasat Bakong and Srah Srang commune identify access to clean water as a critical issue as there is no piped water and villagers rely on groundwater for all household needs. Despite the level of awareness regarding the quality of water, they have noted that it is not tested for hazardous substances. Those who can afford to do so, often boil water for drinking. Very few households can afford bottled water and all use groundwater for washing, bathing and cooking. As there is no requirement to seek permission, they often bore wells to access groundwater. Villagers are aware of the poor quality of the groundwater and store the water in plastic cans for several days to eliminate any pollutants. Groundwater access is unregulated; hence, there is no available data on volumes extracted and the quality of that water, as villagers noted that the water is not tested for arsenic or any other hazardous substances.

\section{Liquid and Solid Waste Management Services}

Villagers in Kampong Phluk stated that in the absence of a regular garbage collection service, the majority of households burn solid waste during the dry season and dispose waste into the water in the wet season. A private garbage collection company services the area, albeit occasionally. The varying income streams of households during the dry and wet season determine their financial capacity to afford private service. In the absence of a sewerage system, access to a toilet is limited and varies between households - from septic tanks, sealed concrete pits, lined/unlined pits and overhanging latrines, or open toilets discharging waste into the open spaces around homes. Villagers claim that sometimes they contribute money and hire a service to collect garbage from public places to maintain the cleanliness of the site for tourists. The only exception was the Village Tourist Centre, where it was noted that the centre stores its solid waste at the centre during the wet season and burns it during 
the dry season, while the liquid waste is stored in a concrete tank, pumped by the sewage truck from Siem Reap Town at a cost. During the dry season, residents of Kampong Phluk discharge the sewage into the nearby stream that eventually joins the creeks merging with the Tonle Sap Lake. Poor households either use the toilets of neighbours or use open spaces during the dry season or defecate directly in the open water during the wet season.

Villagers in Srah Srang and nearby villages noted waste disposal as a challenge. Although APSARA manages the solid waste from designated points, villagers were not sure of the garbage collection schedule as the garbage collection truck makes two to three trips each week. A significant number of households burn their domestic garbage and did not give any particular reason for not using the APSARA-provided service. Access to toilet and sewerage systems was identified as another key challenge as few houses have built toilets that discharge into concrete or septic tanks, while others cannot afford to build toilets, hence defecate in the open. Liquid waste from cooking, washing and bathing is discharged in the backyard of the house, creating pools of liquid waste around the villages.

As noted previously PWD can only provide limited service to the city, these services are insufficient to cater to the growing number of commercial buildings, hotels, restaurants and small businesses. Contrary to the claims made by public offices that the drainage system only releases excess rainwater into the river, it was observed that at various points these drain pipes were used for sewerage drainage as well — even though the source of this water was not visible, the stench of the sewerage at various locations was unmistakeable. These open sewers are visible during the dry season, while in the rainy season, they are hidden from public view due to the swollen water levels.

Small businesses on both sides of the river cater to tourists, while the small vendors provide inexpensive food to locals working in the area, yet one hardly finds a garbage bin for the disposal of food scrapings or plastic bottles, containers and small shopping bags used for handling food. Considering the number of tourists visiting the area and local culture of street food, the amount of single-use plastic containers and bags, pollutants and solid/liquid waste going into the river is enormous and continues to have negative impact on water and the environment. 


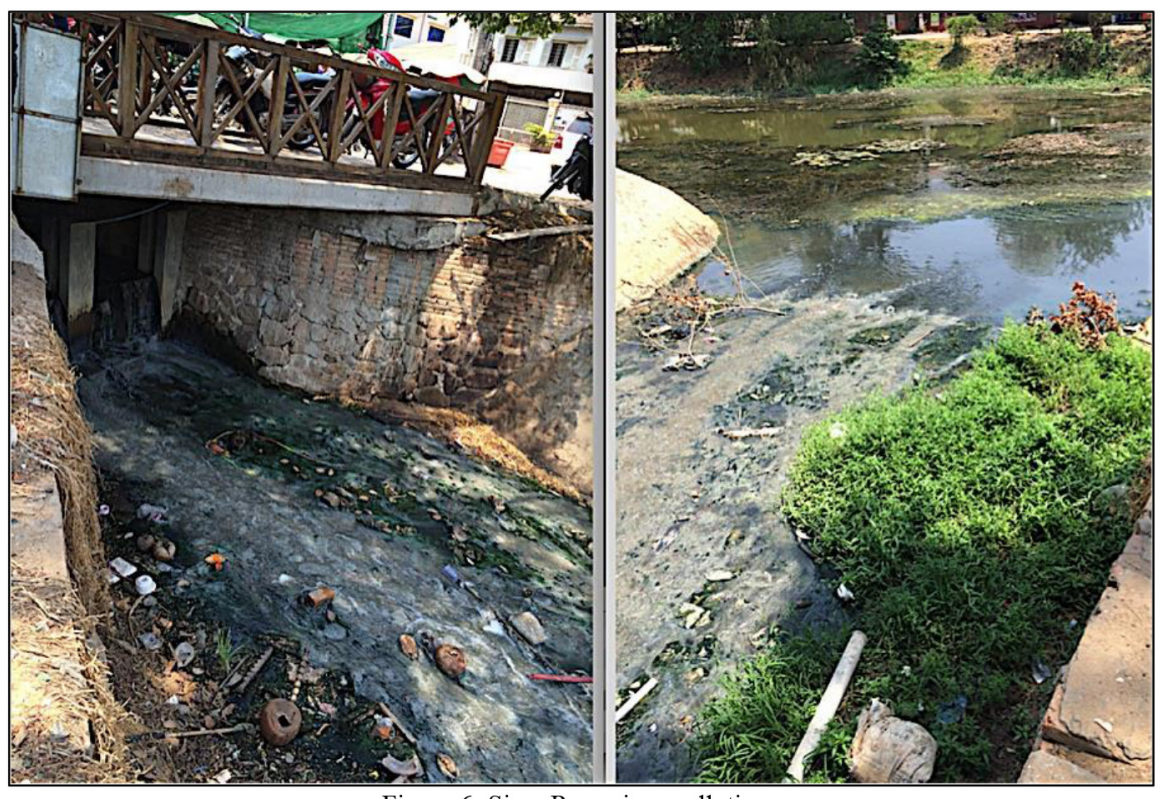

Figure 6: Siem Reap river pollution.

\section{Environment, Changing Landscape and Livelihoods}

Cultural heritage and natural resources attract tourists due to their unique value in human history and natural beauty; however, approaches to attract and increase tourism can potentially reduce the cultural heritage and environmental assets to mere economic commodities, pushing their socio-cultural significance and value to the periphery. Although environmental management was noted as a concern by the policy makers, communities have made subtle references to changing landscape, urban expansion, shrinking of agricultural land, and the quality of air and water linking it to increased tourism and internal migration.

During the field trip, a lot of landfill activity in Kampong Phluk was witnessed; small trucks were extracting sand from the lakesides and filling the gaps under the temple and many surrounding huts (built on wooden poles). The private service is unregulated though one truck driver claimed that if excavation is for the temples or stupa, there is no need to seek permission, however, operators also supply sand to many village houses for a fee (USD7 per truckload at the time of this research), as villagers want access to the road throughout the year. It would be premature to conclude if landfills will impact tourism to the Kampong Phluk floating village or communities during the wet season with easy road access to the village. It is necessary to critically examine the tension between living cultures from the perspective of communities, not merely from the tourist experience perspective. 


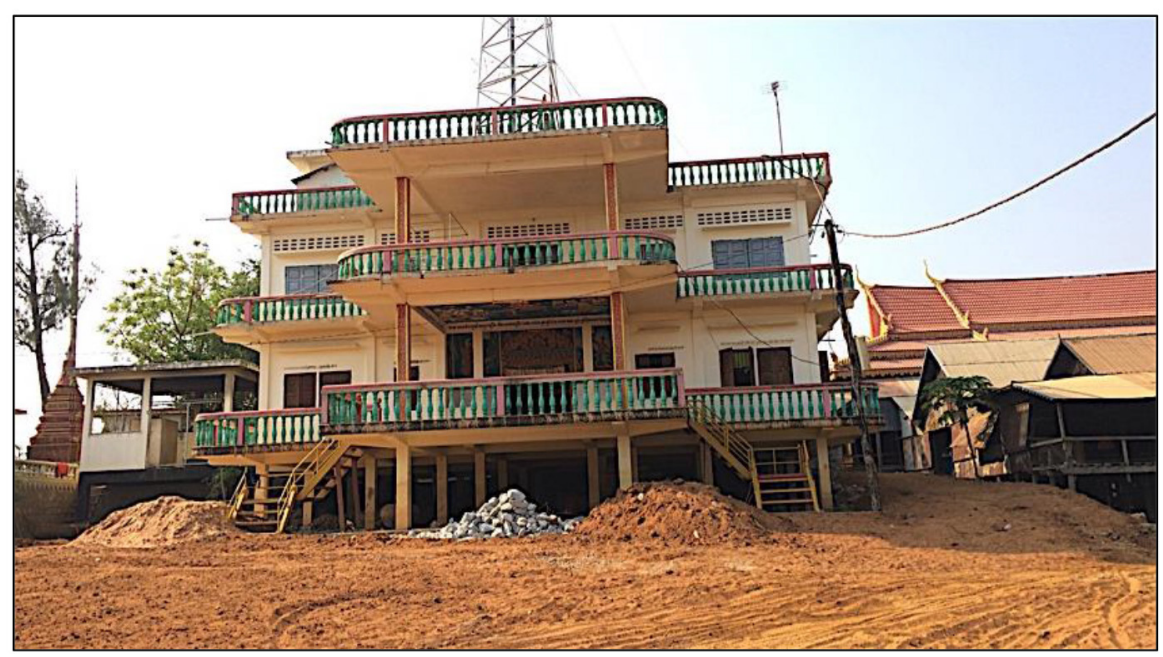

Figure 7: Landfill at local temple in Kampong Phluk.

Kampong Phluk villagers rely heavily on fishing, not only to feed families but to serve to the tourists from their shacks and homes in the wet season and also selling in the local market. Fishermen take tourists to the lake to watch birds, fish, and experience the culture and bring business for local restaurants and small vendors. During the wet season, fishing with smaller boats is possible, however, these boats are not fit to go further into the lake during the dry season, and any prolonged dry season adversely impacts fishing communities, as fishermen have to spend more time at the lake to get fish. Women who generally run small restaurants catering for tourists grow vegetables on the lakebed during the dry season as an alternative source of income. Water and food security were noted without exception as a challenge for locals as well as the tourism sector due to reliance on imports.

\section{Tourism and Challenges for Small Businesses}

Vendors in Psar Leu Market, Samaki Market, Old Market, Angkor Art Centre Market and Siem Reap downtown note employment, income, water, and liquid and solid waste management as key challenges. These markets stock a range of goods, such as fruit and vegetables, poultry and meat, kitchenware, clothes, shoes, jewellery, toiletries and personal utilities, and small household hardware. Khmer New Year in April is the beginning of festivities and religious celebrations but also marks the commencement of the local wedding season, resulting in the increased sale of clothes, jewellery and personal items. Samaki Market is a wholesale market that remains open all night, a source for retailers from Psar Leu Market to buy produce. These two markets primarily cater to local customers, though one can see occasional foreign faces/expat 
NGO workers. Vendors state that sales are up during the dry season when locals from nearby villages come to the market. The sale of poultry, meat, eggs and vegetables increases when the peak freshwater fishing season ends in February. At the end of the wet season, villagers are no longer occupied in farming and after the harvesting, have money to spend on building and repairing houses. Hauser-Schäublin (2011) has noted the extent and volume of imported products sold as local produce despite their origin in Vietnam or Thailand, noting the unequal participation of locals in economic development through tourism in Cambodia.

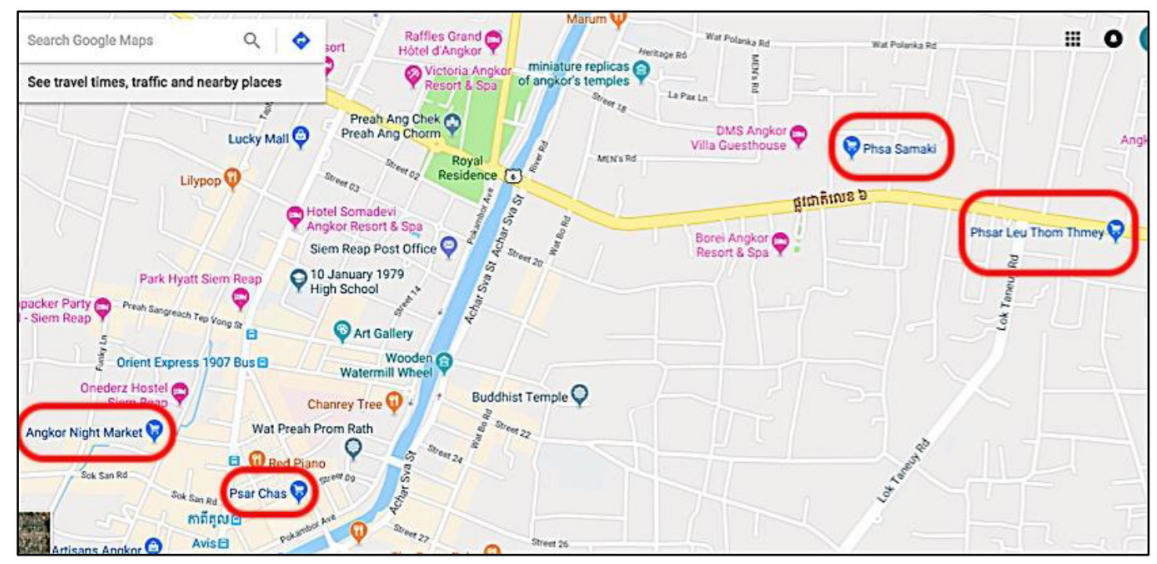

Figure 8: Local market—consultation sites.

Vendors complain that with new markets and shopping areas being built around town, their sales continue to drop. Old Market and Angkor Art Centre Market in Siem Reap Town cater to local and foreign tourists alike, and their businesses boom in the peak tourism season (November-March). These vendors sell souvenirs, clothes, jewellery and handicrafts though largely imported from Thailand, China and Vietnam (Eng 2010; Mao 2015), although the old market remains more popular with tourists as compared to other local markets (Leu and Samaki). Unlike villagers in the archaeological park, small businesses and vendors in these markets do not have the option of subsistence farming, and struggle during the off-peak tourism season as they still have business and personal expenses to meet. Vendors in all markets feel trapped in these markets, as they cannot afford to move to new markets due to high rent, taxes and competition from businesses operated by wealthier enterprises. Biddulph's work with communities and businesses on Psa Kroum Road in Siem-Reap indicates that on the "back street" people have generally benefitted from tourism related activities in a less regulated environment than areas within Zone 1 of the archaeological park, and are mainly migrants from other provinces, or foreigners working in partnership with Cambodians 
(Biddulph 2017). Anecdotal evidence from stories shared by locals indicate that those who did not have the skills or the experience to run a business have subsequently squandered the money earned from the sale of homes, on risky business ventures. It must be acknowledged that local communities are often ill prepared for the changes taking place around them. Even though they benefit from urban expansion, tourism and business opportunities and adapt to these changes, many are left behind struggling to survive. Though policy makers make decisions with good intentions to create economic opportunities, for locals and provide sustainable livelihoods, the benefits have not been shared equitably among all stakeholders. APSARA's recent campaign about zoning and land sale in the archaeological park is a good initiative to raise community awareness.

\section{CONCLUSION}

During fieldwork consultations with various stakeholders, the impact of tourism and natural resource management was examined from the perspective of local communities, while the management of natural resources, tourism development and welfare of local communities from the policy makers' perspective. Policy makers and local communities identified several positive and negative impacts of increased tourism on natural resources as well as local cultural. For policy makers, the increased tourism is an opportunity as well as a challenge, as they must maintain a balance between the need to develop infrastructure, provide goods and services while preserving physical and natural resources within their mandate and with available resources. The challenges are exacerbated due to the lack of reliable GIS data, trained professionals and institutional capacities. Dual governance structures at the national and local levels lead to frustrations, as coordination between various ministries and directorates remains a challenge, and access to information from the rigmarole of bureaucracies is near impossible. For the policy makers, attracting investment in the tourism sector is key to generate revenue and employment, increase tourism and improve infrastructure as well as services to enhance the experience of tourists.

For local communities, changing urban and rural landscape is at odds with local cultural heritage and the natural environment, and there is a feeling of loss of cultural identity and connection with unique Khmer culture, but they also appreciate the positive impact of tourism and employment opportunities created for local communities. Alonso's conclusions on developing tourism 
industry from RB theory perspective in Uruguay (2017) are similar to this research, noting seasonality of employment, revenue generation and impact on local population, as well as the need to offer improved tourist experiences. The debates around cultural heritage require deeper engagement to understand and prioritise cultural preservation, not only from the perspective of local communities but also from the tourist perspective. Changing demographics is not the only issue faced by policy makers and local communities; urban expansion is also leading to an end to traditional subsistence farming. Similar to the findings of this research, Bello et al. (2016) argue for rethinking engagement of communities living in protected areas through tourism planning. From their work in Malawi, they suggest active community participation, awareness, meaningful participation, capacity building and better linkages across sectors. Botswana's "community based cultural heritage resources management" model (Keitumetse 2014) using cultural resources as sustainability enablers can be adapted for Siem Reap/Angkor communities, especially for villages located in Zone 1 in archaeological park.

This research also concludes that there is little recognition that irrespective of insufficient regulatory frameworks, implementation of the existing frameworks is a shared responsibility of all stakeholders, not only of the policy makers. Policy makers are aware of the limitations and lack of a world standard water supply and sanitation and sewerage system in Siem Reap/Angkor region, as well as insufficient garbage collection services. A notable challenge is lack of awareness regarding environmental protection by locals as well as tourists who contribute to environmental degradation. Local communities as well as small businesses also need to play a role in reducing waste especially single use plastic, and disposal of waste into the river and the lake as it impacts water quality.

Siem Reap/Angkor sites are intercultural zones, requiring a deeper understanding of the challenges from nature and human systems as well as from the community perspective. Policy makers need to understand and incorporate what "sustainable development and sustainable livelihoods" means from key stakeholder's perspective as locals have anxieties around losing their material and cultural identity, which need to be addressed. The anxieties need to be understood in the context of socio-cultural perspectives and not reduced to employment opportunities alone. 


\section{ACKNOWLEDGEMENTS}

The author would like to thank the editorial board of International Journal of Asia Pacific Studies and the three anonymous reviewers for their invaluable suggestions and constructive critiques, without which the article would not be in its present form. The author would like to acknowledge that this research work was funded by UNESCO Jakarta - Regional Science Bureau for Asia and the Pacific through a research consultancy (contract no. 4500295275). This paper is a revised and updated version of an earlier report submitted to UNESCO office Jakarta, and is significantly different. The views expressed in the article are of the author and not UNESCO's viewpoint on the topic.

\section{NOTE}

* Tahmina Rashid is an Associate Professor of International Studies, Faculty of Arts and Design, University of Canberra Australia. She has a $\mathrm{PhD}$ and MA from the University of Melbourne, Australia, and a master's degree in Political Science from University of the Punjab, Pakistan. She has previously served as Associate Dean for Academic Affairs at College of Arts and Sciences, Qatar University; Program Director International Development, RMIT University, Australia; and as Assistant Professor, Political Science in Pakistan. She was a Fulbright scholar in 1996 and was also awarded "Asia Fellow Award," Ford Foundation in 2004-2005 to work in urban slums in Dhaka, Bangladesh. Her previous work includes Contested Representations: Punjabi Women in Feminist Debates in Pakistan and International Development: Linking Academia with Development Aid and Effectiveness. She is a development consultant and field researcher with a keen interest in South Asian region. She has worked with UNWomen, UNESCO, Gunn Rural Management International (GRM) and Scope Global as international consultant. Her academic interests include: religious extremism and politics of migration, identity and citizenship; feminist movements in South Asia; sustainable development and human rights; micro-credit and women's empowerment; and conflict and post-conflict humanitarian assistance. https://orcid.org/0000-0002$7731-4628$

\section{REFERENCES}

ADB. 2012. Cambodia: Water supply and sanitation sector assessment, strategy, and road map. https://www.adb.org/sites/default/files/institutional-document/33593/files/ cam-water-supply-sanitation-sector-assessment.pdf (accessed 10 January 2019).

Agranoff, R. 2012. Collaborating to manage. Washington: Georgetown University Press. Alonso, A. D. 2017. Exploring a developing tourism industry: A resource-based view approach. Tourism Recreation Research 42 (1): 45-58, https://doi.org/10.1080/02 508281.2016.1239332. 
Andersen, O. and Kheam, L. S. 1998. Resource-based theory and international growth strategies: An exploratory study. International Business Review 7 (2): 163-184, https://doi.org/10.1016/S0969-5931(98)00004-3.

Andre, M-F. et al. 2014. Accelerated stone deterioration induced by forest clearance around the Angkor temples. Science of the Total Environment 493: 98-108, https://doi. org/10.1016/j.scitotenv.2014.05.141.

Angkor Enterprise. 2017. Annual report 2017. https://www.angkorenterprise.gov.kh/ annual-news/2017/5/report (accessed 10 January 2019).

Angrosino, M. 2007. Doing ethnographic and observational research. London: Sage.

Ansel, C. and Gash, A. 2007. Collaborative governance in theory and in practice. Journal of Public Administration, Research and Theory 18 (4): 543-571, https://doi. org/10.1093/jopart/mum032.

Banks, S. and Brydon-Miller, M. 2019. Ethics in participatory research. In Ethics in participatory research for health and social well-being: Cases and commentaries, eds. Banks, S. and Brydon-Miller, M., 1-30. New York: Routledge.

Barney, J. 1991. Firm resources and sustained competitive advantage. Journal of Management 17 (1): 199-120, https://doi.org/10.1177\%2F014920639101700108. . 2001. Is the resource-based "view" a useful perspective for strategic management research? Yes. Academy of Management Review 26 (1): 41-56, https://doi. org/10.5465/amr.2001.4011938.

.2018. Why resource-based theory's model of profit appropriation must incorporate a stakeholder perspective. Strategic Management 39 (13): 3305-3325, https://doi. org/10.1002/smj.2949.

Barney, J. and Clark, D. N. 2007. Resource-based theory: Creating and sustaining competitive advantage. New York: Oxford University Press.

Barney, J. B., Ketchen, D. and Wright, M. 2011. The future of resource-based theory: Revitalization or decline? Journal of Management 37 (5): 1299-1315, https://doi. org/10.1177\%2F0149206310391805.

Bebbington, A. 1999. Capitals and capabilities: A framework for analyzing peasant viability, rural livelihoods and poverty. World Development 27 (12): 2021-2044, https://doi.org/10.1016/S0305-750X(99)00104-7.

Bello, F. G., Lovelock, B. and Carr, N. 2016. Enhancing community participation in tourism planning associated with protected areas in developing countries: Lessons from Malawi. Tourism and Hospitality Research 18 (3): 309-320, https://doi.org/1 $0.1177 \% 2 F 1467358416647763$.

Bernstein, R. 2017. China's Mekong plans threaten disaster for countries downstream. ForeignPolicy.com, https://foreignpolicy.com/2017/09/27/chinas-mekong-plansthreaten-disaster-for-countries-downstream/ (accessed 17 March 2019).

Bharam, V. 2012. River cities of Asia: Challenges for sustainable development of Lijianng, Siem Reap and Vientiane. Unpublished paper, Trinity College, Hartford, CT. http:// commons.trincoll.edu/vbharam/files/2013/03/Final-paper.pdf (accessed 10 January 2019).

Biddulph, R. 2017. Tourist territorialisation and geographies of opportunity at the edges of mass destinations. Tourism Geographies 19 (1): 27-43, https://doi.org/10.1080/14 616688.2016.1217920. 
Bonnafous-Boucher, M. and Rendtorff, J. D. 2016. Stakeholder theory: A model for strategic management. Bern: Springer.

Brennan, E. 2018. China eyes its next prize - the Mekong. LowyInstitute.org, https:// www.lowyinstitute.org/the-interpreter/china-eyes-its-next-prize-mekong (accessed 17 March 2019).

Brickell, K. 2008. "Fire in the house": Gendered experiences of drunkenness and violence in Siem Reap, Cambodia. Geoforum 39 (5): 1667- 1675, https://doi.org/10.1016/j. geoforum.2008.04.002.

Byrd, E. T. 2007. Stakeholders in sustainable tourism development and their roles: Applying stakeholder theory to sustainable tourism development. Tourism Review 62 (2): 6-13, https://doi.org/10.1108/16605370780000309.

CANARI. 2011. Facilitating participatory natural resource management: A toolkit for Caribbean managers. Laventille: CANARI.

Candelaria, M. A. F. 2005. The Angkor sites of Cambodia: The conflicting values of sustainable tourism and state sovereignty. Brooklyn Journal of International Law 31 (1): 253-288.

Chambers, R. and Conway, G. 1992. Sustainable rural livelihoods: Practical concepts for the 21 st century. Discussion paper 296, Institute of Development Studies. http:// publications.iwmi.org/pdf/H_32821.pdf (accessed 10 January 2019).

Chamroeun, S. 2015. Enhancing and restoring water systems in Angkor World Heritage site and Siem Reap City Project. Unpublished report, UNESCO, Jakarta. . 2017. Angkor water crisis. UNESCO.org, https://en.unesco.org/courier/2017april-june/angkor-water-crisis (accessed 17 March 2019).

Chen, F. et al. 2017. Radar interferometry offers new insights into threats to the Angkor site. Science Advances 3 (3): 1-8, https://www.doi.org/10.1126/sciadv.1601284.

Chheang, V. 2008. The political economy of tourism in Cambodia. Asia Pacific Journal of Tourism Research 13 (3): 281-297, https://doi.org/10.1080/10941660802280414. . 2010. Tourism and local community development in Siem Reap. Ritsumeikan Journal of Asia Pacific Studies 27: 85-101.

Clifford, J. 1990. Notes on (field) notes. In Field notes: The makings of anthropology, ed. Sanjek, R., 47-70. New York: Cornell University Press.

Colbry, S., Hurwitz, M. and Adair, R. 2014. Collaboration theory. Journal of Leadership Education 13 (4): 63-75, https://doi.org/10.12806/V13/I4/C8.

Conner, K. R. 1991. A historical comparison of resource-based theory and five schools of thought within industrial organization economic: Do we have a new theory of the firm. Journal of Management 17 (1): 121-154, https://doi.org/10.1177\% 2F014920639101700109.

D'Anselmi, P. 2011. Values and stakeholders in an era of social responsibility: Cut-throat competition? New York: Palgrave-Macmillan.

Dabney, D. A. and Tewksbury, R. 2016. Speaking truth to power. Oakland, CA: University of California Press.

Denscombe, M. 2010. The good research guide for small-scale social research projects. Berkshire: Open University Press.

DeWalt, K. M. and DeWalt, B. R. 2011. Participant observation: A guide for fieldworkers. Plymouth: AltaMira Press. 
Doherty, B. 2010. Private water raiding threatens Angkor's temples built on sand. The Guardian Online, https://www.theguardian.com/world/2010/sep/27/water-raidingthreatens-angkor-wat (accessed 17 March 2019).

Dolezal, C. and Trupp, A. 2015. Tourism and development in Southeast Asia. ASEASAustrian Journal of South-East Asian Studies 8 (2): 117-124, https://doi.org/10. 10.14764/10.ASEAS-2015.2-1.

Donaldson, T. 2011. The inescapability of a minimal version of normative stakeholder theory. In Stakeholder theory: Impact and prospects, ed. Philips, R. A., 130-139. Cheltenham: Edwards Elgar.

Donaldson, T. and Preston, L.E. 1995. The stake-holder theory of the corporation: Concepts, evidence, and implications. The Academy of Management Review, 20 (1): 65-91, https://doi.org/10.5465/amr.1995.9503271992.

Eden, C. and Ackermann, F. 1998. Making strategy: The journey of strategic management. London: Sage.

Emerson, K., Nabatchi, T. and Balogh, S. 2012. An integrative framework for collaborative governance. Journal of Public Administration Research and Theory 22 (1): 1-29, https://doi.org/10.1093/jopart/mur011.

Eng, D. 2010. The impacts of tourism on the society of Srah Srang Cheung Cillage, Angkor Park. Masters diss., Auckland University of Technology, New Zealand.

Esposito, A. 2014. Planning urban development from an outsider's perspective: Siem Reap, the backdrop of changing urban representations. Anthropologia 1 (1): 143-154, https://doi.org/10.14672/ada2014259\%25p.

Freeman, R. E. 1984. Strategic management: A stakeholder approach. Boston: Pitman. . 2011. Some thoughts on the development of stakeholder theory. In Stakeholder theory: Impact and prospects, ed. Philips, R. A., 212-234. Cheltenham: Edwards Elgar.

Freeman, E. et al. 2010. Stakeholder theory: The state of the art. New York: Cambridge University Press.

Friedman, A. L. and Miles, S. 2006. Stakeholders: Theory and practice. Oxford: Oxford University Press.

Gillespie, J.2013. World Heritage management:Boundary-making at Angkor Archaeological Park, Cambodia. Journal of Environmental Planning and Management 56 (2): 286-304, https://doi.org/10.1080/09640568.2012.657868.

Graduate School of International Development (GSID). 2013. Overseas fieldwork report 2013: Siem Reap Province, Cambodia. Nagoya: GSID, Nagoya University. https:// www2.gsid.nagoya-u.ac.jp/blog/fieldwork/files/2014/10/2013-OFW-Report-Final. pdf (accessed 10 January 2019).

Grant, R. M. 1991. The resource-based theory of competitive advantage: Implications for strategy formulation. California Management Review 33 (3): 114-135, https://doi. org/10.2307\%2F41166664.

Gray, B. 1985. Conditions facilitating interorganizational collaboration. Human Relations 38 (10): 911-936, https://doi.org/10.1177\%2F001872678503801001.

Gerson, K. and Horowitz, R. 2002. Observations and interviewing: Options and choices in qualitative research. In Qualitative research in action, ed. May, T., 199-224. London: Sage.

Gregory, I. 2003. Ethics in research. London: Continuum. 
Hakim, L. 2018. Cambodia real estate highlights. KnightFrank.com, https:// content.knightfrank.com/research/1471/documents/en/cambodia-real-estatehighlights-h1-2018-5808.pdf (accessed 17 March 2019).

Harrison, J. S. 2011. Stakeholder theory in strategic management: A retrospective. In Stakeholder theory: Impact and prospects, ed. Philips, R. A., 99-110. Cheltenham: Edwards Elgar.

Hauser-Schäublin, B. 2011. New chances for local farmers and artisans? In World heritage Angkor and beyond: Circumstances and implications of UNESCO listings in Cambodia, ed. Hauser-Schäublin, B., 177-202. Göttingen: Göttingen University Press.

Hays, J. 2008. Tonle Sap. FactsandDetails.com, http:/factsanddetails.com/southeast-asia/ Cambodia/sub5_2f/entry-3506.html (accessed 10 January 2018).

Hitt, M. A., Xu, K. and C, C. M. 2016. Resource based theory in operations management research. Journal of Operations Management 41: 77-94, https://doi.org/10.1016/j. jom.2015.11.002.

Jamal, T. B. and Getz, D. 1995. Collaboration theory and community tourism planning. Annals of Tourism Research 22 (1): 186-204, https://doi.org/10.1016/01607383(94)00067-3.

Jamal, T. and Stronza, A. 2009. Collaboration theory and tourism practice in protected areas: Stakeholders, structuring and sustainability. Journal of Sustainable Tourism 17 (2): 169-189, https://doi.org/10.1080/09669580802495741.

Kaiser, K. 2009. Protecting respondent confidentiality in qualitative research. Qualitative Health Research 19 (11): 1632-1641, https://doi.org/10.1177\% 2F1049732309350879.

Keitumetse, S. O. 2014. Cultural resources as sustainability enablers: Towards a Community-Based Cultural Heritage Resources Management (COBACHREM) model. Sustainability 6 (1): 70-85, https://doi.org/10.3390/su6010070.

Kiguchi, Y. 2016. Impacts of dam construction on the Mekong: The experience of the Mun River. MekongWatch.org, http://www.mekongwatch.org/PDF/ MekongDam_20160223_report.pdf (accessed 17 March 2019)

Kim, K. 1991 Tourism on our terms: Tourism planning in Hawaii. Denver, CO: Western Governors Association.

King, N. 2018. Navigating hydro-power along the Mekong River. InternationalAffairs.org, https://www.internationalaffairs.org.au/resource/navigating-hydro-power-alongthe-mekong-river/ (accessed 17 March 2019).

Laws, S., Harper, C. and Marcus, R. 2003. Research for development: A practical guide. London: Sage.

Liu, X. et al. 2018. Water is a critical factor in evaluating and assessing microbial colonization and destruction of Angkor sandstone monuments. International Biodeterioration and Biodegradation 133: 9-16.

Maijoor, S. and Witteloostuijn, A. V. 1996. An empirical test of the resource-based theory: Strategic regulation in the Dutch audit industry. Strategic Management Journal 17:549-569, https://doi.org/10.1002/(SICI)1097-0266(199607)17:7\%3C549::AIDSMJ827\%3E3.0.CO;2-R.

Mao, N. 2015. The role of tourism industry in poverty reduction: A case study of Siem Reap-Angkor region, Cambodia. PhD diss., Victoria University, Australia. 
Mao, N. et al. 2014. Agriculture and tourism linkage constraints in the Siem Reap-Angkor region of Cambodia. Tourism Geographies 16 (4): 669-686, https://doi.org/10.108 $0 / 14616688.2014 .915878$.

Margerum, R. D. 2008. A typology of collaboration efforts in environment management. Environmental Management 41 (4): 487-500, https://doi.org/10.1007/s00267-0089067-9.

McNamara, M. 2012. Starting to untangle the web of cooperation, coordination, and collaboration: A framework for public managers. International Journal of Public Administration 35: 389-401, https://doi.org/10.1080/01900692.2012.655527.

Ministry of Tourism, Cambodia. 2017. Tourism statistics report 2017. https://www. tourismcambodia.com/img/resources/cambodia_tourism_statistics_2017.pdf (accessed 17 March 2019).

Morse, S. and McNamara, N. 2013. Sustainable livelihood approach: A critique of theory and practice. London: Springer.

Nothnagel, K. 2008. Empirical research within resource-based theory. Wiesbaden: Gabler Edition Wissenschaft.

Nutt, P. and Backoff, R. 1992. Strategic management of public and third sector organizations: A handbook for leaders. San Francisco, CA: Jossey-Bass.

Oels, A. 2006. Evaluating stakeholder dialogues. In Stakeholder dialogues in natural resources management, eds. Stoll-Kleemann, S. and Welp, M., 117-152. Springer: Berlin-Heidelberg.

Olson, K. R. and Morton, L. W. 2018. Water rights and fights: Lao dams on the Mekong River. Journal of Soil and Water Conservation 73 (2): 35A-41A, https://doi. org/10.2489/jswc.73.2.35A.

Orr, S. K. 2014. Environmental policymaking and stakeholder collaboration. Boca Raton, FL: CRC Press.

Orts, E. W. and Strudler, A. 2002. The ethical and environmental limits of stakeholder theory. Business Ethics Quarterly 12 (2): 215-233, https://doi.org/10.2307/3857811.

Ourng, C. et al. 2011. Modeling urban growth pattern for sustainable archaeological sites: A case study in Siem Reap, Cambodia. Unpublished paper, Department of Civil Engineering, University of Mindo, Portugal. https://core.ac.uk/download/ pdf/55624069.pdf (accessed 17 March 2019).

Ourng, C. and Rodrigues, D. S. 2012. Urban growth pattern identification: A case study in Siem Reap, Cambodia. Unpublished paper, https://core.ac.uk/download/ pdf/55623243.pdf (accessed 17 March 2019).

Pesqueux, Y. and Damak-Ayadi, S. 2005. Stakeholder theory in perspective. Corporate Governance: The International Journal of Business in Society 5 (2): 5-21, https:// doi.org/10.1108/14720700510562622.

Ponna, P. and Prasiasa, D. P. O. 2011. Community participation for sustainable tourism in heritage site: A case of Angkor, Siem Reap province, Cambodia. Mudra 26 (3): 306-313.

Peter, M., Siller, L. and Matzler, K. 2011. The resource-based and the market-based approaches to cultural tourism in alpine destinations. Journal of Sustainable Tourism 19 (7): 877-893, https://doi.org/10.1080/09669582.2010.547198.

Preserving Angkor: Interview with Ang Choulean. 2000. TaleofAsia.com, http://www. talesofasia.com/cambodia-interviews-AC.htm (accessed 10 January 2019). 
Priem, R. L. and Butler, J. E. 2001. Is the resource-based "view" a useful perspective for strategic management research? Academy of Management Review 26 (1): 22-40, https://doi.org/10.5465/AMR.2001.4011928.

Punch, K. 2014. Introduction to social science research. London: Sage.

Rabé, P. E. 2008. Siem Reap: Urban development in the shadow of Angkor. The Getty, https://www.getty.edu/conservation/our_projects/education/sea/final_report 2008 _pacrim.pdf (accessed 10 January 2017).

Räsänen, T. A. et al. 2017. Observed river discharge changes due to hydropower operations in the Upper Mekong Basin. Journal of Hydrology 545: 28-41. https://doi. org/10.1016/j.jhydrol.2016.12.023.

Rittel, H. W. J. and Webber, M. M. 1973. Dilemmas in a general theory of planning. Policy Sciences 4: 155-169, https://doi.org/10.1007/BF01405730.

Sachs, S., Ruhli, E. and Kern, I. 2009. Sustainable success with stakeholders: The untapped potential. New York: Palgrave-Macmillan.

Sachs, S. and Ruhli, E. 2011. Stakeholders matter: A new paradigm for strategy in society. New York: Cambridge University Press.

Sautter, E. T. and Leisen, B. 1999. Managing stakeholders: A tourism planning model. Annals of Tourism Research 26 (2): 312-328, https://doi.org/10.1016/S01607383(98)00097-8.

Scoones, I. 1998. Sustainable rural livelihoods: A framework for analysis. Working paper 72, Institute of Development Studies, Brighton.

Scoones, I. and Wolmer, W. 2003. Introduction: Livelihoods in crisis? New perspectives on governance and rural development in South Africa. IDS Bulletin 34 (3).

Seidman, I. 2013. Interviewing as qualitative research: A guide for researchers in education and the social sciences. New York: Teachers College Press, Columbia University.

Sekiguchi, M. and Hatsukano, N. 2013. Land conflicts and land registration in Cambodia. In Land and post-conflict peacebuilding, eds. Williams, U. and Williams, R. C., 437-450. London: Earthscan.

Shane, J. 2016. Confidential informants: A closer look at police policy. New York: Springer.

Sotheary, P. 2017. Illegal building at Angkor site must go, says UNESCO. Khmer Times, 27 June. https://www.khmertimeskh.com/16366/illegal-building-at-angkor-sitemust-go-says-unesco/ (accessed 17 March 2019). .2019. Apsara authority puts up signs to foil land grabs. Khmer Times, 18 February. https://www.khmertimeskh.com/50579040/apsara-authority-puts-up-signs-to-foilland-grabs-2/ (accessed 17 March 2019).

Soubert, S. and Soung, L. H. 1995. Case study on the effects of tourism on culture and the environment: Cambodia. UNESCO.org, http://unesdoc.unesco.org/ images/0012/001226/122618eo.pdf (accessed 10 January 2019).

Spiess, R. 2018. Ticket revenue at Angkor Wat jumps 72 percent after price hike. The Phnom Penh Post, 2 January. https://www.phnompenhpost.com/business/ticket-revenueangkor-wat-jumps-72-percent-after-price-hike (accessed 10 October 2018).

Surmiak, A. 2018. Confidentiality in qualitative research involving vulnerable participants: Researchers' perspectives. Forum Qualitative Social Research 19 (3): 1-26, https:// doi.org/10.17169/fqs-19.3.3099.

Tolley, E. E. et al. 2016. Qualitative methods in public health: A field guide for applied research. San Francisco: Wiley. 
Tosun, C. 2000. Limits to community participation in the tourism development process in developing countries. Tourism Management 21 (6): 613-633, https://doi. org/10.1016/S0261-5177(00)00009-1.

UNESCO et al. 2018. International migration in Southeast Asia: An initiative to better understand migrants' experiences and develop inclusive policy responses. UNESCO.org, https://unesdoc.unesco.org/ark:/48223/pf0000261362 (accessed 17 March 2019).

United Nations. 2012. Cambodian government's achievements and future direction in sustainable development. National Report for Rio+20 United Nations Conference on Sustainable Development. https://sustainabledevelopment.un.org/content/ documents/1022cambodia.pdf (accessed 10 January 2019).

Visvanathan, S. 2009. Knowledge, justice and democracy. In The environmental responsibility reader, eds. Reynolds, M., Blackmore, C. and Smith, M. J., 150-158. London: Zed Books.

Warnier, V. and Weppe, X. 2013. Extending resource-based theory: Considering strategic, ordinary and junk resources. Management Decision 51 (7): 1359-1379, https://doi. org/10.1108/MD-05-2012-0392.

Wernerfelt, B. 1984. A resource-based view of the firm. Strategic Management Journal 5 (2): 171-180, https://doi.org/10.1002/smj.4250050207.

Williams, A. P. 2016. The development of collaboration theory: Typologies and systems approaches. In Advancing collaboration theory, eds. Morris, J. C. and Miller-Stevens, K., 14-42. New York: Routledge.

Winter, T. 2008. Post-conflict heritage and tourism in Cambodia: The burden of Angkor. International Journal of Heritage Studies 14 (6): 524-539, https://doi. org/10.1080/13527250802503274.

World Travel and Tourism Council. 2018. Travel and tourism: Economic impact 2018 Cambodia. https://www.wttc.org/-/media/files/reports/economic-impact-research/ countries-2018/cambodia2018.pdf (accessed 17 March 2019). 